\title{
Reduction in oxidative stress levels in the colonic mucosa without fecal stream after the application of enemas containing aqueous Ilex paraguariensis extract ${ }^{1}$
}

\author{
Redução dos níveis de estresse oxidativo na mucosa cólica sem trânsito intestinal após \\ aplicação de enemas contendo extrato aquoso de Ilex paraguariensis
}

\author{
Fernando Lorenzetti da Cunha', Camila Morais Gonçalves da Silva ${ }^{\mathrm{II}}$, Marcos Gonçalves de Almeida ${ }^{\mathrm{III}}$, Thais Miguel do Monte \\ Lameiro $^{\mathrm{I}}$, Letícia Helena Souza Marques ${ }^{\mathrm{IV}}$, Nelson Fontana Margarido ${ }^{\mathrm{V}}$, Carlos Augusto Real Martinez ${ }^{\mathrm{VI}}$ \\ ${ }^{1}$ Research performed at the Postgraduate Program in Health Sciences, Sao Francisco University (USF), Bragança Paulista-SP, and the Laboratory of \\ Medical and Surgical Research (LIM-02) of FMUSP, Sao Paulo, Brazil.

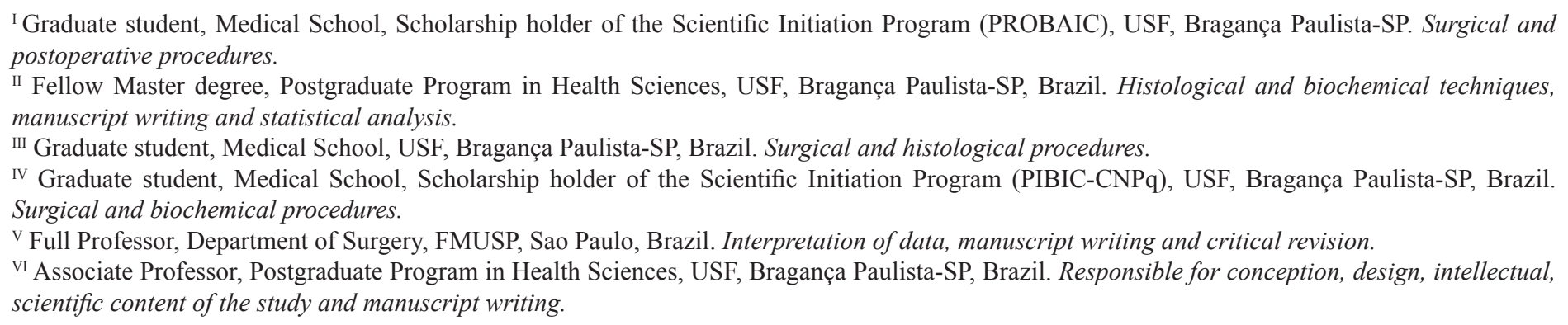

\section{ABSTRACT}

Purpose: To evaluate the antioxidant effects of enemas containing aqueous extract of Ilex paraguariensis, comparing segments with and without fecal stream and correlating the segments with the duration of intervention. Methods: Twenty-six Wistar rats were subjected to a diversion of the fecal stream in the left colon by a proximal colostomy and distal mucosal fistula. The rats were distributed randomly into two experimental groups of 13 animals each based on the time of sacrifice after surgical procedure (two or four weeks). Each group was then divided into two experimental subgroups that received either second daily enemas containing $0.9 \%$ saline solution or aqueous extract of Ilex paraguariensis at $0.2 \mathrm{~g} / 100 \mathrm{~g}$. Colitis was diagnosed by histopathological analysis and the detection of oxidative tissue damage by measuring the levels of malondialdehyde. The Mann-Whitney test was used to compare the tissue levels of malondialdehyde between colon segments with and without fecal stream in each experimental group, and the Kruskal-Wallis test was used to verify the variance between the levels of oxidative stress according the duration of the irrigation; both tests determined significance at $5 \%$ $(p<0.05)$. Results: The levels of malondialdehyde in the animals subjected to intervention in the colon with saline with and without fecal stream after two and four weeks of irrigation were $0.05 \pm 0.006$ and $0.06 \pm 0.006$, and $0.05 \pm 0.03$ and $0.08 \pm 0.02$, respectively. The malondialdehyde levels in the animals irrigated with Ilex paraguariensis with and without fecal stream after two and four weeks of irrigation were $0.010 \pm 0.002$ and $0.02 \pm 0.004$, and $0.03 \pm 0.007$ and $0.04 \pm 0.01$, respectively. After two and four weeks of intervention, the levels of malondialdehyde were lower in the animals irrigated with Ilex paraguariensis regardless of the time of irrigation ( $\mathrm{p}=0.0001$ and $\mathrm{p}=0.002$, respectively). Conclusion: The daily rectal application of enemas containing aqueous extract of Ilex paraguariensis decreases oxidative tissue damage in the colon without fecal stream regardless of the time of irrigation.

Key words: Colon. Colitis. Oxidative Stress. Ilex paraguariensis. Lipid Peroxidation. Malondialdehyde. Rats.

\section{RESUMO}

Objetivo: Avaliar os efeitos antioxidantes de clisteres contendo extrato aquoso de Ilex paraguariensis comparando segmentos com e sem trânsito fecal e correlacionando com o tempo de intervenção. Métodos: Vinte e seis ratos Wistar machos foram submetidos à derivação do trânsito no cólon esquerdo pela confecção de colostomia proximal e fístula mucosa distal. Foram divididos de forma randomizada em dois grupos experimentais de 13 animais, de acordo com o sacrifício ser realizado após duas ou quatro semanas do procedimento cirúrgico. Cada grupo foi dividido em dois subgrupos experimentais segundo a aplicação diária ter sido realizada com enemas diários contendo solução fisiológica a $0,9 \%$ ou extrato aquoso de Ilex paraguariensis na concentração de $0,2 \mathrm{~g} / 100 \mathrm{ml}$. O diagnóstico de colite foi estabelecido por análise histológica e os níveis de estresse oxidativo pela dosagem tecidual de malondialdeído Para comparar os níveis de malondialdeído entre os cólons com e sem trânsito fecal em cada grupo experimental adotou-se o teste de Mann-Withney, e o teste de Kruskal-Wallis para verificar a variação dos níveis de estresse oxidativo segundo o tempo de irrigação, estabelecendo-se 
para ambos o nível de significância de $5 \%(\mathrm{p}<0,05)$. Resultados: Os níveis de malondialdeído nos animais submetidos à intervenção com soro fisiológico nos cólons providos e desprovidos de trânsito fecal após duas e quatro semanas de irrigação foram de $0,05 \pm 0,006$, $0,06 \pm 0,006$ e $0,05 \pm 0,03,0,08 \pm 0,02$ respectivamente. Os níveis de malondialdeído nos animais irrigados com Ilex paraguariensis, nos cólons providos e desprovidos de trânsito, após duas e quatro semanas de irrigação foram de $0,010 \pm 0,002,0,02 \pm 0,004$ e $0,03 \pm 0,007$, $0,04 \pm 0,01$, respectivamente. Após duas e quatro semanas de intervenção os níveis de malondialdeído foram menores nos animais irrigados com Ilex paraguariensis, independente do tempo de irrigação ( $\mathrm{p}=0,0001$ e $\mathrm{p}=0,002$, respectivamente). Conclusão: A aplicação diária de extrato aquoso de Ilex paraguariensis reduz os níveis de dano oxidativo tecidual nos segmentos cólicos sem trânsito fecal, independente do tempo de irrigação.

Descritores: Cólon. Colite. Estresse oxidativo. Ilex paraguariensis. Peroxidação de Lipídeos. Malondialdeído. Ratos.

\section{Introduction}

Mate tea (Ilex paraguariensis) is a native tree species of the Aquifoliaceae family, which is found mainly in Brazil, Argentina and Paraguay ${ }^{1,2}$. Previous research has shown that compounds found in mate tea, mainly polyphenols, have antioxidant, antiinflammatory, immunomodulatory and anticancer effects ${ }^{3,4}$. Clinical and experimental studies in animal models indicate that flavonoids, a type of polyphenol, exert beneficial effects due to their antioxidant properties ${ }^{5}$. Compounds with antioxidant activity have been widely studied for their applicability in the chemoprevention of inflammation and colorectal carcinogenesis ${ }^{6}$. Thus, the inhibition of any one of the multiple stages of carcinogenesis could potentially prevent the onset of cancer ${ }^{6}$. In a complementary manner, experimental and epidemiological studies indicate a growing interest in the use of natural substances with antioxidant activity in chemoprevention because of their wide availability, low costs and ability to inhibit tumor initiation and/ or promotion ${ }^{7}$.

Polyphenols or phenolic compounds are a large group of molecules found in teas, fruits, vegetables, cereals, coffee, cocoa, wine and soy. In plants, they protect against insects and microorganisms and are responsible for pigmentation and some organoleptic characteristics of food $^{8}$. Recently, natural polyphenolic substances such as curcumin (extract from Curcuma longa) and revesterol (extract from grapes) are being increasingly used as antioxidant substances in different experimental models of colitis ${ }^{9,10,11,12}$. Although it has been demonstrated experimentally that the pathogenesis of diversion colitis (DC) is related to oxidative stress due to changes in the supply of short-chain fatty acids (SCFA) to the excluded colon, to the best of our knowledge, the antioxidant effects of natural polyphenols in the aqueous extract of Ilex paraguariensis have not been evaluated in the treatment of colitis ${ }^{13}$. It is possible that the polyphenolic compounds in the aqueous extract of Ilex paraguariensis can reduce the levels of oxidative stress and inflammation in the colonic mucosa. The aim of the present study was to determine if enemas containing
Ilex paraguariensis aqueous extract could reduce the levels of oxidative and tissue damage in the colonic mucosa devoid of fecal stream.

\section{Methods}

This study was conducted in accordance with Federal Law No. 11.794 (10/08/2008) and the guidelines of the Brazilian College for Animal Experimentation (COBEA). The study was approved by the Ethics Committee in Animal Research of Sao Francisco University.

Male SPF Wistar rats (300-350g) were obtained from the CEMIB (State University of Campinas, Sao Paulo, Brazil). Animals were housed in the Sao Francisco University School of Medicine barrier facility, maintained in 12-hour light/dark cycles, and fed a standard rodent chow diet. The animals were deprived of food, but not water, for 12 hour prior to the surgical procedure.

The fecal stream was deverted in all animals under general anesthesia by intramuscular administration of $0.1 \mathrm{ml} / 100 \mathrm{~g}$ of a $1: 1$ (v/v) solution of ketamine $(50 \mathrm{mg} / \mathrm{ml})$ and xylazine $(20 \mathrm{mg} / \mathrm{ml})$. The abdomen was shaved, and a 3-cm-long midline incision was made. The left colon was exteriorized and sectioned in its mid-portion corresponding to the descending colon, approximately $3 \mathrm{~cm}$ above the Peyer's lymphoid patch in the rectal-sigmoid transition. Two circular skin pellets, 3-mm in diameter and 3-cm apart, were made in the left side of the abdominal wall at the same vertical level. The proximal end of the colon was exteriorized through the cranial cutaneous orifice, and the distal stoma was exteriorized through the caudal skin opening after splitting the abdominal wall muscles. The proximal end and the distal stoma were fixed to the skin with full-thickness sutures of Prolene 5-0 (Ethicon Inc., Somerville, NJ, USA). Before the fixation of the distal stoma to the skin, the distal colon was cleaned with an infusion of a physiologic solution until the fecal contents were completely removed. The abdominal incision was closed in two layers; the muscle and aponeurosis were closed with Vicryl 4-0 (Ethicon Inc., Somerville, NJ, USA), and the skin was closed with nylon 4-0 (Ethicon Inc., Somerville, NJ, 
USA). In this way, two colostomies were performed: the proximal colostomy as a terminal colostomy with intestinal transit and a second colostomy as a distal stoma devoid of the fecal stream. Rats were maintained in individual cages without particular care being taken with regard to the stomas and abdominal incisions.

\section{Experimental groups}

The twenty-six animals submitted to deviation of the fecal stream as described above were randomly divided into two experimental groups with 13 animals each being sacrificed 2 or 4 weeks after the surgical procedure. Each experimental group was divided into two subgroups according to the intervention solution employed to irrigate the rectum. In the first subgroup, four animals received daily rectal enemas containing $40 \mathrm{ml}$ heated $\left(37^{\circ} \mathrm{C}\right) 0.9 \%$ saline solution (control subgroup). In the second subgroup, nine animals received daily rectal enemas containing $40 \mathrm{ml}$ lyophilized aqueous extract of Ilex paraguariensis (Leao Jr, Curitiba-PR, Brazil) solubilized in water at a concentration of $0.2 \mathrm{~g} / 100 \mathrm{~g}$ (experimental subgroup).

The mate tea used in this study contained $350 \mathrm{mg} / \mathrm{g}$ phenolic compounds, as determined by the Folin-Ciocalteau methodology using 5-caffeoylquinic acid as the standard for the calibration curve ${ }^{4}$. The Ilex paraguariensis mate tea enema was prepared fresh each day by dissolving lyophilized instant mate tea in water using a homogenizer. The aqueous mate tea and vehicle (saline solution) were administered to colon segments without fecal stream by enemas per anus and were continuously irrigated with $40 \mathrm{ml}$ saline or extract of Ilex paraguariensis for one minute to ensure that the entire colonic mucosa was exposed to the intervention solution.

\section{Sample collection}

Upon completion of the pre-determined irrigation period (two or four weeks), the animals were anesthetized as described above, and the midline incision was reopened. In both groups, two fragments $(2.0 \mathrm{~cm}$ in length) were taken from the intraabdominal part of the excluded (colon without fecal stream) and non-excluded segments (colon with fecal stream). The removed specimens were longitudinally opened through the anti-mesenteric border. The longitudinal fragments were histologically analyzed and the levels of malondialdehyde (MDA) were determined as an indicator of oxidative tissue damage (lipid peroxidation). The fragments evaluated for mucosal MDA levels were separated from the other layers of the colon wall by dissection with an entomologic magnifying glass.

Analysis of polyphenolic compounds in aqueous extract of Ilex paraguariensis by mass spectrometry

Analysis was performed by negative ion mode ESI-MS fingerprinting. The equipment was cleaned using a methanol/ water solution containing $0.1 \%$ ammonium hydroxide to remove potential interferences, and the equipment was then calibrated with a solution of $0.1 \%$ formic acid. A 50-mg sample was weighted and homogenized in $1 \mathrm{~mL}$ methanol and water. The material was filtered, and $10 \mu \mathrm{L}$ was diluted in $990 \mu \mathrm{L}$ prepared solution of methanol/water with $0.1 \%$ ammonium hydroxide. The samples were analyzed using a flow injection rate of $10 \mu \mathrm{L} /$ minute.

\section{Histological analysis}

Fragments prepared for histological analysis were immersed in 10\% neutral buffered formalin (Sigma, St. Louis, MO, USA) for $24 \mathrm{~h}$, dehydrated in increasing ethanol concentrations, and embedded in paraffin. Thereafter, 5 - $\mu \mathrm{m}$ sections of tissue were cut using a rotary microtome (Leica Biosystems, Nussloch, Germany), mounted on glass slides, cleared, hydrated and stained with hematoxylin-eosin (HE) for histological evaluation. Slide analysis was performed by a pathologist experienced in inflammatory bowel diseases who was unaware of the source material and the objectives of the study using an optical microscope (Eclipse DS50, Nikon Inc., Osaka, Japan) at a final magnification of $200 \times$. Photomicrographs were taken with a digital video-capture camera (DS-Fi-50; Nikon Inc., Osaka, Japan) coupled to the microscope body and digitized for image analysis (NIS-Elements; Nikon Inc., Osaka, Japan). Colitis was diagnosed based on the presence of three independent histological parameters: reduction of the crypt length, neutrophil infiltration of the mucosa and submucosa and epithelial erosion or ulceration.

\section{Determination of the levels of malondialdehyde (MDA)}

The levels of lipid oxidation were assessed by measuring the levels of thiobarbituric acid-reactive substances (TBARS), such as MDA, as previously described ${ }^{14,15}$. MDA is a secondary product of lipid oxidation and is considered a potential candidate as a general biomarker of oxidative tissue stress. For the quantification of tissue levels of MDA, $1 \mathrm{~g}$ of each fragment was placed in $5 \mathrm{~mL}$ phosphate buffer and homogenized in a vortex and the ultra-sonicator for 30 seconds, alternately repeating the process 
three times. Then, $250 \mu \mathrm{L}$ of the supernatant obtained from the homogenization process was transferred to a plastic tube containing $25 \mu \mathrm{L} 4 \%$ methanolic BHT and again homogenized by vortexing. The sample was then mixed with $1 \mathrm{~mL} \mathrm{12 \%}$ trichloroacetic acid, $1 \mathrm{~mL} 0.73 \%$ thiobarbituric acid and $750 \mu \mathrm{L}$ Tris/ $\mathrm{HCl}$ buffer and incubated in a water bath at $100^{\circ} \mathrm{C}$ for 60 minutes. After this step, sample tubes were immediately placed in a container with ice to block the reaction, and $1.5 \mathrm{~mL}$-butanol was then added and mixed by vortexing again for 30 seconds. The samples were separated by centrifugation for 10 minutes at 5,000 rpm. Finally, the supernatant was removed, and the absorbance at $532 \mathrm{~nm}$ of the organic phase was analyzed using a spectrophotometer UV/VIS 6105 (Jenway, Bibby Scientific Limited, Staffordshire,UK).

\section{Statistical analysis}

The statistical analysis of the results obtained was performed using a significance level of $5 \%(p<0.05)$. The data obtained from the colon segment analyzed in each experimental group were expressed as mean values along with the respective standard deviation using SPSS for Windows statistical software (version 13.0). The Mann-Whitney test was used to compare inflammation scores between the control and experimental group animals (segments with and without fecal stream) and the tissue levels of MDA. The Kruskal-Wallis test was used to analyze the variance in MDA tissue levels between the different experimental subgroups.

\section{Results}

Figure 1 shows the spectra of the polyphenolic constituents derived from chlorogenic acid identified in aqueous extract of Ilex paraguariensis used in the present sudy.

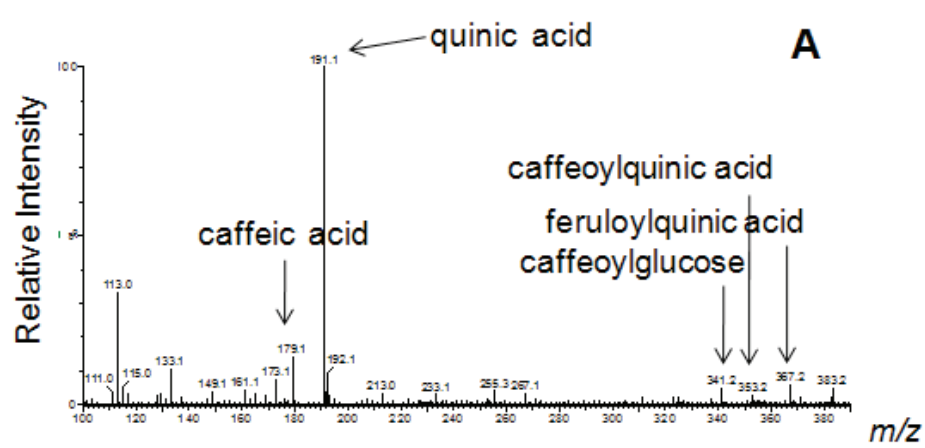

FIGURE 1 - ESI(-)-MS of mate tea (Ilex paraguariensis).
Animals treated with saline for two or four weeks with or without fecal stream showed reduced crypt length, neutrophil mucosal and submucosal infiltration levels and greater epithelial erosion than animals treated with aqueous extract of Ilex paraguariensis (Figure 2). Independent of treatment, the reduction in crypt length, neutrophilic infiltration and epithelial erosions were greater at four weeks post-treatment than at two weeks posttreatment in colon segments without fecal stream.

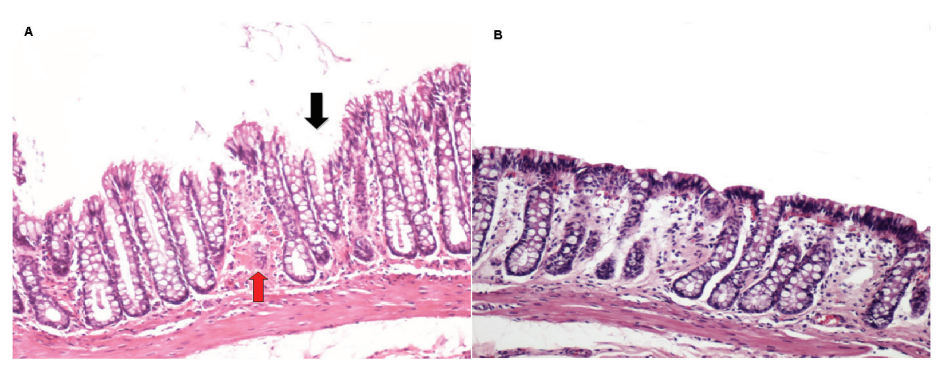

FIGURE 2 - A. Segment of the colon without fecal stream irrigated with saline for 4 weeks showing epithelial ulcers (black arrow) and mucosal edema (red arrow). B. Segment of the colon without fecal stream irrigated for 4 weeks with aqueous extract of the Ilex paraguariensis. (HE, 100×).

Figure 3 shows the levels of MDA in segments with and without fecal stream in animals irrigated with saline compared to those irrigated with Ilex paraguariensis aqueous extract for two weeks. The results show that both irrigated and non-irrigated segments of the animals irrigated with aqueous extract of Ilex paraguariensis exhibited lower levels of MDA than those of the control group.

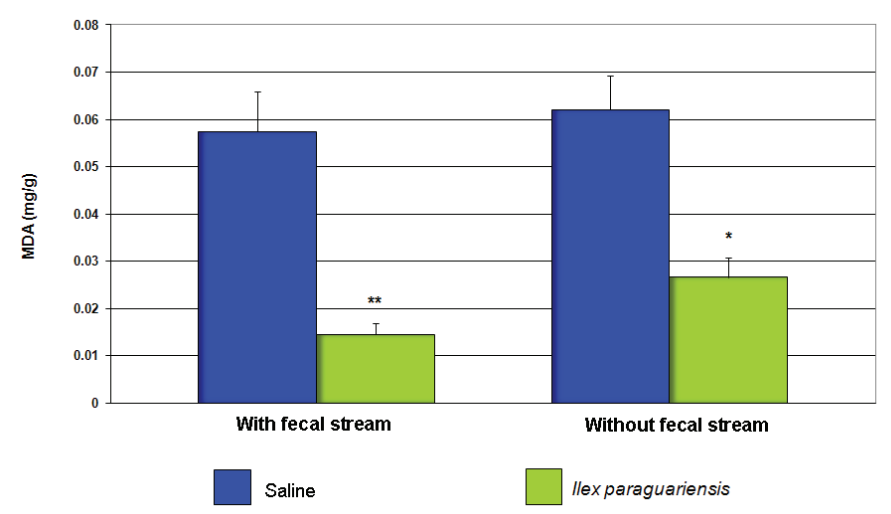

FIGURE 3 - Tissue levels of MDA in colon segments with and without fecal stream irrigated for two weeks with aqueous extract of Ilex paraguariensis or saline. ${ }^{* *}$ significant; $\mathrm{p}<0.05$. Mann Whitney test.

Figure 4 shows the levels of MDA in segments with and without fecal stream after irrigation with saline or Ilex paraguariensis for four weeks. The results show that both the irrigated and non-irrigated segments of the animals undergoing 
treatment with Ilex paraguariensis exhibited MDA levels that were lower than those of animals subjected to intervention with $0.9 \%$ saline.

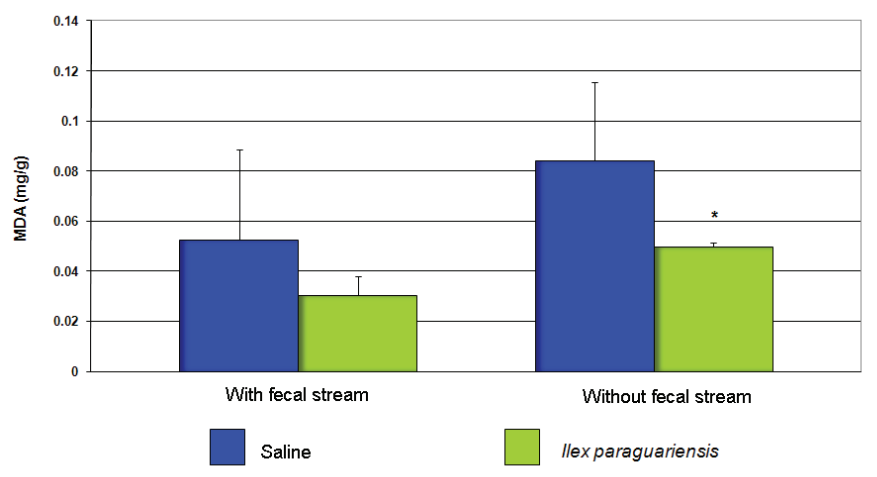

FIGURE 4 - Tissue levels of MDA comparing colon segments with and without fecal stream from animals that underwent irrigation for two weeks with aqueous extract of Ilex paraguariensis or saline. ${ }^{* *}$ significant; $\mathrm{p}<0.05$. Mann Whitney test.

Figure 5 shows the variations of the tissue levels of MDA in colon segments with and without fecal stream after two or four weeks of irrigation with saline or aqueous extract of Ilex paraguariensis. The colon segments without fecal stream showed greater levels of MDA compared to the colonic segments with fecal stream, and these levels increased with the time of exclusion. Daily application of aqueous extract of Ilex paraguariensis was shown to reduce the levels of oxidative tissue damage in the colon without fecal stream compared to other solution studies.

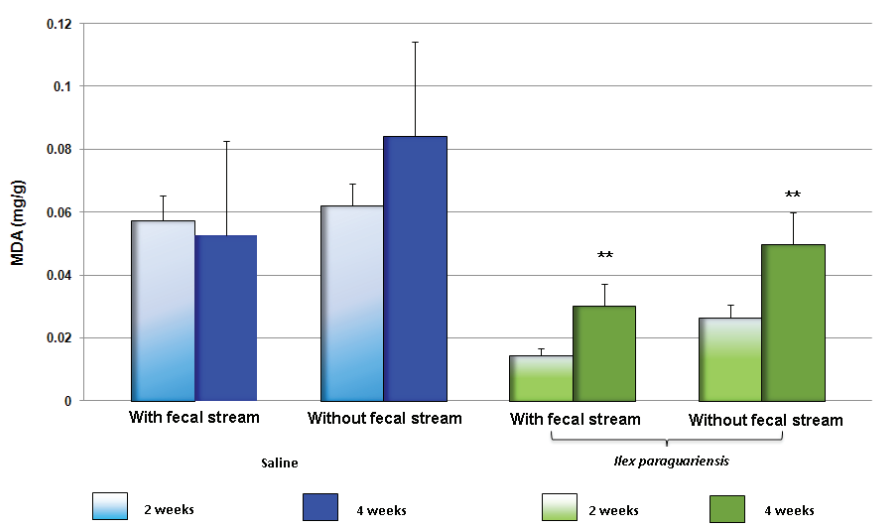

FIGURE 5 - Tissue levels of MDA comparing colon segments with and without fecal stream irrigated for two or four weeks with saline or aqueous extract of Ilex paraguariensis. ${ }^{* *}$ significant; $\mathrm{p}<0.05$. Kruskal-Wallis test.

\section{Discussion}

In recent years, the importance of the role of reactive oxygen species (ROS) in the etiopathogenesis of ulcerative colitis and other inflammatory diseases that affect the colon mucosa, such as DC, has increased ${ }^{13,16,17,18,19}$. Likewise, experimental studies have confirmed the role of ROS in the development of chemically induced colitis by acetic acid, TNBS and DSS $20,21,22,23$.

Free radicals are atoms or molecules with an odd number of electrons in their outer electronic shells, making the molecule highly reactive ${ }^{24}$. ROS is the adopted name because most free radicals are generated from the cellular metabolism of oxygen. The ROS are constantly formed during respiration of all living cells ${ }^{13,24}$. Most of the ROS are formed during oxidative phosphorylation within mitochondria ${ }^{14}$. When they are produced in excess, ROS are harmful to cells and damage proteins, membranes, organelles and nucleotide bases, which can results in genetic mutations ${ }^{25,26,27,28,29}$. Cells have developed defense mechanisms to maintain the balance between ROS production and neutralization and avoid oxidative stress $^{12,25-27}$. The colon mucosa is particularly vulnerable to oxidative stress $^{23}$. Studies have shown that the antioxidant systems in the colonic mucosa are deficient compared to other organs and tissues, making it more susceptible to oxidative stress ${ }^{30}$. Colonic mucosa oxidative stress occurs more frequently and intensely than in other organs because of its the constant exposure to antigens and oxidizing substances formed within the intestinal lumen ${ }^{13,23}$.

The pathogenesis of inflammatory bowel disease has been attributed to several factors, with emphasis placed on leukocyte infiltration and increased production of proinflammatory cytokines. The tissue damage to the colonic mucosa has been attributed to the large capacity of the activated neutrophils to produce $\operatorname{ROS}^{16,19}$. Tissue fragments collected from patients with ulcerative colitis showed greater activity in lipid peroxidation levels compared to normal tissue ${ }^{31}$. Experimental studies using animals with acetic acid induced-colitis also found elevated levels of lipid peroxidation in the acute phase of disease ${ }^{22,23}$. A recent study using an experimental model of diversion colitis demonstrated that colonic mucosa devoid of a fecal stream exhibited an increase in the ROS production, higher tissue levels of COX-2, and increased levels of oxidative damage to DNA, although there was less neutrophil infiltration measured by tissue levels of myeloperoxidase ${ }^{32}$. The importance of oxidative stress in the pathogenesis of DC is enhanced by studies that have shown that substances used in the treatment of ulcerative colitis, such as 5-aminosalicylic acid (5-ASA), exert its therapeutic effect simply by inhibiting the production of oxygen free radicals in neutrophils ${ }^{33}$.

Although the levels of oxidative stress can be measured with different methods, all confirm the direct relationship between increased formation of ROS and colonic mucosal damage ${ }^{21,24}$. Of the 
various methods used to measure oxidative stress, detecting MDA content is one of the most frequently used. MDA is a secondary product of lipid peroxidation, and it is derived from the $\beta$-rupture of polyunsaturated fatty acids such as linoleic acid, arachidonic and docosahexaenoic acids. The quantification of tissue levels of MDA is a simple implementation technique for assessing the intensity of the oxidation of cellular phospholipids. In this technique, the tissue levels of MDA were determined by spectrophotometry like one substances that react with thiobarbituric acid (TBARS) $)^{3,15}$.

Mate tea (Ilex paraguariensis) is one of the most widely consumed plants in South America. Mate tea is rich in several bioactive compounds such as caffeine, phenolic acids and saponins, which are absorbed by the body and may act as antioxidants or free radical scavengers ${ }^{2-4}$. The fingerprinting performed by mass spectrometry in this study demonstrates the presence of polyphenol compounds with antioxidant activity derived from chlorogenic acid in the aqueous extract of Ilex paraguariensis. Previous studies showed that these derivatives of chlorogenic acid have antioxidant activity by reducing the levels of oxidative damage to cellular DNA ${ }^{3,4}$. The chlorogenic acids that seem to have anti-inflammatory activity as well as the ability to inhibit carcinogenesis are the main polyphenols in mate tea $^{4}$. Experimental studies evaluating the antioxidant effects of the administration of aqueous extract of Ilex paraguariensis showed that regular ingestion of mate tea increased the resistance of DNA oxidative stress and improved the DNA repair after $\mathrm{H}_{2} \mathrm{O}_{2}$ challenge in liver cells irrespective of the dose ingested ${ }^{4}$. These effects may be caused by the antioxidant activity of the bioactive compounds in mate tea. In this study, the polyphenols responsible for the antioxidant power of Ilex paraguariensis were detected by MS fingerprinting. However, to the best of our knowledge, no study to date has evaluated the potential antioxidant effect of aqueous extract of Ilex paraguariensis in experimental models of DC. If the compounds are demonstrated to be effective in reducing the levels of lipid peroxidation, the use of enemas containing concentrated antioxidant compounds from the plant may potentially reduce ROS-induced damage to the colonic mucosa. Because of the high bioavailability of the active components and the low cost of the tea, this approach might be a valid alternative for the treatment of a disease increasingly diagnosed in clinical practices.

One of the most important factors that should be considered in the efficacy of antioxidant substances is the form of administration. Studies have demonstrated that the topical application of 5-ASA via enemas, foams or suppositories had a better therapeutic efficacy than oral administration ${ }^{34}$. The use of enemas with 5-ASA directly in the inflamed region could achieve adequate tissue concentrations, even when using small volumes, thus making this route of administration an appealing option ${ }^{22}$. When administered orally, the drug is distributed throughout the body and does not reach the same concentration in colon tissue compared to administration in the form of enemas ${ }^{23,35}$. This becomes particularly relevant when considering that most patients with ulcerative colitis and DC have a higher involvement of the final portions of the colon and rectum ${ }^{36}$. The rectum is the most frequently deprived segment of intestinal transit due to the higher prevalence of stoma caused by diseases localized in the distal colon and rectum. Moreover, Hartmann's procedure for emergency treatment, diverticulitis, obstructive cancer of the sigmoid colon, rectal and perineal trauma is the most widely used procedure in these conditions. For all of these reasons, we opted for the implementation of the intervention solutions by enemas. We believe that administration by enemas directs the active ingredient directly to the affected colon, allowing better evaluation of its antioxidant effect in the ideal form of administration.

The results of this study showed that although colitis was confirmed in all samples, the histological results showed that irrigation of the affected colon with aqueous extract of Ilex paraguariensis was efficient in reducing the epithelial damage in colon segments without fecal stream. As expected, the colon without fecal stream showed further reduction of the crypt length, mucosal neutrophil infiltration and epithelial erosions regardless of treatment, compared with the colon segments with preserved fecal streams. This observation is in agreement with previous studies by our own group proving that the colon without fecal stream, in the absence of SCFA, is more exposed to the action of ROS, which can lead epithelial damage ${ }^{13}$.

The results seem to confirm the importance of a regular supply of SCFA to maintain homeostasis of the oxidative metabolism of the cells lining the colon. We found that despite the fact that levels of MDA were lower in animals irrigated with aqueous extract of Ilex paraguariensis, they were higher in segments without fecal stream, confirming the importance of maintaining a steady supply of SCFA in the prevention of DC. We found a significant reduction in the levels of MDA in the segments with fecal stream after two weeks of irrigation with Ilex paraguariensis when compared with those irrigated with saline. These results suggest that the application of enemas with antioxidant compounds of the aqueous extract of Ilex paraguariensis in the segments without fecal stream has systemic effects, most likely as a result of the absorption of these substances by rectal mucosa.

We found that after two weeks of daily enemas with 
Ilex paraguariensis in the colon devoid of the fecal stream, the levels of MDA both in the segments with and without transit were lower than those irrigated with saline. Nevertheless, the levels of MDA the colon without transit in the animals irrigated with Ilex paraguariensis were lower despite presenting a higher level of MDA compared with fecal stream. These results demonstrate the antioxidant effects of topical application of enemas with Ilex paraguariensis.

In animals irrigated for four weeks with saline, the levels of MDA in segments with or without fecal stream were similar, indicating that irrigation with saline does not reduce the level of damage either by local effects or by the systemic effect. These observations were different in the animals irrigated with aqueous extract of Ilex paraguariensis, although the levels of MDA in the excluded colon were higher than those of the colon with fecal stream in both segments and were smaller compared to those animals irrigated with saline. These results confirm that aqueous extract of Ilex paraguariensis maintain local and systemic antioxidant effects after application for four weeks in rats, which in humans, would correspond to a major period. However, the systemic effects do not seem as evident when compared to animals irrigated for two weeks. It is possible that these results are related to the reduction in the ability of the drug absorbed by the affected colon mucosa because of the reduction in the absorption surface caused by the atrophy of intestinal crypts ${ }^{37}$.

When we analyzed the variation in the levels of MDA in the colon with and without fecal stream in the animals irrigated for two or four weeks based on the two intervention solutions, we found that the aqueous extract of Ilex paraguariensis significantly reduced the variation in the levels of MDA, regardless of the time of irrigation. We found a decrease in the MDA levels in the colon with and without fecal stream, indicating that the natural extract exhibits antioxidant activity both locally and systemically. When we assessed the levels of MDA in the colons by comparing the two periods of irrigation, we found that the levels of MDA, even as they increased with increasing time, were always lower after four weeks in the animals irrigated with aqueous extract of Ilex paraguariensis. These results show that the antioxidant effects of the phenolic compounds of Ilex paraguariensis are able to maintain the oxidative cell membrane damage at levels significantly lower when compared with saline over time.

The results found in the present study suggest that daily rectal enemas containing aqueous extract of Ilex paraguariensis in an experimental model of DC has antioxidant properties and seems to be beneficial in reducing the mucosal oxidative stress of both colon segments with and without fecal stream. They also suggest that the use of antioxidant compounds of the aqueous extract of Ilex paraguariensis is an alternative for the treatment and prevention of DC. However, studies with large numbers of human patients still must be performed to determine if the results found in this experimental model can be extrapolated to humans.

\section{Conclusion}

The daily application of enemas with aqueous extract of Ilex paraguariensis can decrease the levels of oxidative stress in the colon segments without fecal stream.

\section{References}

1. Maccari Junior A, Mazuchowski JZ. Produtos alternativos e desenvolvimento da tecnologia industrial na cadeia produtiva da erva-mate. 1.ed. Curitiba: Câmara Setorial da Cadeia Produtiva da Erva-Mate/ Ministério da Ciência e Tecnologia-PADCT; 2000.

2. Ribeiro AS, Cruz AT, Urias VC. O agronegócio da erva-mate: um grande potencial sul-mato-grossense a ser explorado. Seminário em Administração FEA-USP, VII SEMEAD; 2004.

3. Bastos DHM, Saldanha LA, Catharino RR, Sawaya ACHF, Cunha IBS, Carvalho PO, Eberlin MN. Phenolic antioxidants identified by ESI-MS from yerba maté (Ilex paraguariensis) and green tea (Camelia sinensis) extracts. Molecules (Basel). 2007;12:423-32.

4. Miranda DDC, Arcari DP, Pedrazzoli Junior J, Carvalho PO, Cerutti SM, Bastos DHM, Ribeiro ML. Protective effects of mate tea (Ilex paraguariensis) on $\mathrm{H}_{2} \mathrm{O}_{2}$-induced DNA damage and DNA repair in mice. Mutagenesis. 2008;23:261-5.

5. Holst B, Williamson, G. Nutrients and phytochemicals: from bioavailability to bioefficacy beyond antioxidants. Curr Opin Biotechnol. 2008;19(2):73-82.

6. Smith JJ, Tully P, Padberg RM. Chemoprevention: a primary cancer prevention strategy. Semin Oncol Nurs. 2005;21(4):243-51.

7. Surh YJ. Cancer chemoprevention with dietary phytochemicals. Nat Rev Cancer. 2003;3:768-80.

8. Escarpa A, Gonzáles MC. An overview of analytical chemistry of phenolic compounds in foods. Crit Rev Anal Chemistry. 2001;31:57.

9. Cui X, Jin Y, Hofseth AB, Pena E, Habiger J, Chumanevich A, Poudyal D, Nagarkatti M, Nagarkatti PS, Singh UP, Hofseth LJ. Resveratrol suppresses colitis and colon cancer associated with colitis. Cancer Prev Res (Phila). 2010;3(4)549-59.

10. Sánchez-Fidalgo S, Cárdeno A, Villegas I, Talero E, de la Lastra CA. Dietary supplementation of resveratrol attenuates chronic colonic inflammation in mice. Eur J Pharmacol. 2010;633:78-84.

11. Camacho-Barquero L, Villegas I, Sánchez-Calvo JM, Talero E, Sánchez-Fidalgo S, Motilva V, Alarcón de la Lastra C. Curcumin, a Curcuma longa constituent, acts on MAPK p38 pathway modulating COX-2 and iNOS expression in chronic experimental colitis. Int Immunopharmacol. 2007;7:333-42.

12. Arafa HM, Hemeida RA, El-Bahrawy AI, Hamada FM. Prophylactic role of curcumin in dextran sulfate sodium (DSS)-induced ulcerative colitis murine model. Food Chem Toxicol. 2009;47:1311-7.

13. Martinez CAR, Ribeiro ML, Gambero A, Miranda DDC, Pereira JA, Nadal SR. The importance of oxygen free radicals in the etiopathogenesis of diversion colitis in rats. Acta Cir Bras. 2010;25:387-95

14. Ohkawa H, Ohishi N, Yagi K. Assay for lipid peroxides in animal tissues by thiobarbituric acid reaction. Anal Biochem. 1979;95:3518 . 
15. Marques LHS, Silva CMG, Lameiro TMM, Almeida MG, Cunha FL, Pereira JA, Martinez CAR. Evaluation of lipid peroxidation levels on mucosa colonic cells after application of hydrogen peroxide in enemas: experimental study in rats. Rev Bras Coloproctol. 2010;30:272-80.

16. Pravda J. Radical induction theory of ulcerative colitis. World $\mathrm{J}$ Gastroenterol. 2005;11(16):2371-84.

17. Kruidenier L, Verspaget HW. Review article: oxidative stress as a pathogenic factor in inflammatory bowel disease: radicals or ridiculous. Aliment Pharmacol Ther. 2002;16:1997-2015.

18. Dryden GW Jr, Deaciuc I, Arteel G, McClain CJ. Clinical implications of oxidative stress and antioxidant therapy. Curr Gastroenterol Rep. 2005; 7:308-16.

19. Rezaie A, Parker RD, Abdollahi M. Oxidative stress and pathogenesis of inflammatory bowel disease an epiphenomenon or the cause. Dig Dis Sci. 2007;52:2015-21.

20. Grisham MB, Volkmer C, Tso P, Yamada T. Metabolism of trinitrobenzene sulfonic acid by the rat colon produces reactive oxygen species. Gastroenterology. 1991;101:540-7.

21. Chamulitrat W, Spitzer JJ. Generation of nitro and superoxide radicals anions from 2,4,6-trinitrobenzenesulfonic acid by rat gastrointestinal cells. Biochim Biophys Acta. 1997;1336:73-82.

22. Damiani CR, Benetton CA, Stoffel C, Bardini KC, Cardoso VH, Di Giunta G, Pinho RA, Dal-Pizzol F, Streck EL. Oxidative stress and metabolism in animal model of colitis induced by dextran sulfate sodium. J Gastroenterol Hepatol. 2007;22:1846-51.

23. Fillmann H, Kretzmann NA, San-Miguel B, Llesuy S, Marroni N, González-Gallego J, Tuñón MJ. Glutamine inhibits over-expression of pro-inflammatory genes and down-regulates the nuclear factor kappaB pathway in an experimental model of colitis in the rat. Toxicology. 2007;236:217-26.

24. Gutteridge JM, Halliwell B. Free radicals and antioxidants in the year 2000. A historical look to the future. Ann N Y Acad Sci. 2000;899:136-47.

25. Ribeiro ML, Priolli DG, Miranda DD, Arçari DP, Pedrazzoli J Jr, Martinez CA. Analysis of oxidative DNA damage in patients with colorectal cancer. Clin Colorectal Cancer. 2008;7:267-72.

26. Cadenas E, Davies KJ. Mitochondrial free radical generation, oxidative stress, and aging. Free Rad Biol Med. 2000;29:222-30.
27. McCord JM. The evolution of free radicals and oxidative stress. Am J Med. 2000;108:652-9.

28. Thannickal VJ, Fanburg BL. Reactive oxygen species in cell signaling. Am J Physiol Lung Cell Mol Physiol. 2000;279:1005-28.

29. Seril DN, Liao J, Yang GY, Yang CS. Oxidative stress and ulcerative colitis-associated carcinogenesis: studies in humans and animal models. Carcinogenesis. 2003;24(3):353-62.

30. Tham DM, Whitin JC, Cohen HJ. Increased expression of extracellular glutathione peroxidase in mice with dextran sodium sulfate-induced experimental colitis. Pediatr Res. 2002;51:641-6.

31. Tuzu A, Erdil A, Inal V, Aydin A, Bagci S, Yesilova Z, Sayal A, Karaeren N, Dagalp K. Oxidative stress and antioxidant capacity in patients with inflammatory bowel disease. Clin Biochem. 2002;35:569-72.

32. Longatti TS, Acedo SC, de Oliveira CC, Miranda DD, Priolli DG, Ribeiro ML, Gambero A, Martinez CA. Inflammatory alterations in excluded colon in rats - a comparison with chemically-induced colitis. Scand J Gastroenterol. 2010;45(3):315-24.

33. Caltabiano C, Máximo FR, Spadari APP, da Conceição Miranda DD, Serra MM, Ribeiro ML, Martinez CA. 5-Aminosalicylic acid (5-ASA) can reduce levels of oxidative DNA damage in cells of colonic mucosa with and without fecal stream. Dig Dis Sci. 2010 Nov 2. [Epub ahead of print]

34. Campieri M, Gionchetti P, Belluzzi A, Brignola C, Tampieri M, Iannone P, Miglioli M, Barbara L. Optimum dosage of 5 -aminosalicylic acid as rectal enemas in patients with active ulcerative colitis. Gut. 1991;32:929-81.

35. Haagen Nielsen O, Bondesen S. Kinetics of 5-aminosalicylic acid after jejunal instillation in man. Br J Clin Pharmacol. 1983;16:73840.

36. Lakatos PL, Lakatos L. Ulcerative proctitis: a review of pharmacotherapy and management. Expert Opin Pharmacother. 2008;9:741-9.

37. Sousa MV, Priolli DG, Portes AV, Cardinalli IA, Pereira JA, Martinez CAR. Evaluation by computerized morphometry of histopathological alterations of the colon wall in segments with and without intestinal transit in rats. Acta Cir Bras. 2008;23:417-24.

\section{Correspondence:}

Carlos Augusto Real Martinez

Rua Rui Barbosa, 255/32

09190-370 Santo André - SP Brasil

Tel: (55 11)4438-9203

caomartinez@uol.com.br
Conflict of interest: none Financial source: $\mathrm{CNPq}$

Received: December 20, 2010

Review: February 21, 2011

Accepted: March 18, 2011 